\title{
Money matters: the financing of the Conservative Party
}

Justin Fisher (Brunel University)

\section{Introduction}

The Conservatives entered the 2001 election in the novel position of being the poorer of the two main parties. Since 1997, Labour's income and expenditure had outstripped that of the Tories. Nevertheless, in the build up to the election at least, some traditional patterns were maintained - the Conservatives received more than Labour in the way of both individual and corporate donations. Even without the $£ 5,000,000$ donation made by Paul Getty days before the election, the Conservatives' volume of individual donations outstripped that of Labour. ${ }^{1}$ In addition, the amount of non-cash donations (donations inkind) received by the Conservatives dwarfed those received by other parties. Of course, the Conservatives lost the election badly, and without the evidence of a sustained electoral recovery, one might have expected the party's income to suffer. This article examines, amongst other things, whether or not this was the case.

\section{Income and Expenditure}

Full details of the party's income and expenditure post the 2001 elections are, at the time of writing, relatively limited. Nevertheless for the period up until December 2002, some patterns emerge. First, donations continue to play a key role in the party's finances. In the twelve months to $31^{\text {st }}$ March 2002, they constituted 52\% of the central party's income, whilst in the nine months to December $31^{\text {st }} 2002$ the figure was $58 \%$. The next largest source of income was state money - mainly in the form of Short and Cranborne money, but also including new grants from the Electoral Commission. In the nine months to 
December $31^{\text {st }} 2002$, this constituted $29 \%$ of the party's income. Finally, income from membership subscriptions and constituency parties remained modest: around 7\% of the income received in the nine months to the end of 2002.

In terms of expenditure, similar patterns observed in the 1990s were apparent - namely that routine expenditure constituted a significant financial burden. Even in the accounting year which included the election (twelve months to March 2002), routine running costs accounted for over $40 \%$ of expenditure, whilst in the nine months to the end of 2002 , the comparable figure was $74 \%$. Added to that, $17 \%$ of expenditure was spent on fundraising. All of which again illustrates the point that parties require significant sums beside elections simply to maintain themselves as going concerns. Parties do have too much money, they have too little.

\section{Conservatives in Comparison}

Making direct comparisons between parties' income and expenditure has, up until recently, been plagued with a certain degree of imprecision. The principal reason for this was that parties' financial year-ends differed. All of this is about to change, with the parties uniting around a December year-end. However, the most current accounts available (ending $31^{\text {st }}$ December 2002) still make exact comparisons difficult - the Conservatives detailing on the nine months up to December $31^{\text {st }}$, Labour the full twelve. Nevertheless, the accounts do reveal that Labour remained the wealthier of the two main parties. The Conservatives raised $£ 9.9$ million compared with Labour’s $£ 21$ million. Even if we add the sums received by the Tories in declared donations for the first quarter on 
2002 (some $£ 1.6$ million), it is clear that Conservative income was some way below that of Labour, as was also the case with expenditure. The silver lining for the Conservatives was that whilst Labour declared net liabilities of some $£ 7$ million, the Tories declared net assets of some $£ 3.6$ million, though this was financed in part by interest free loans repayable on demand from constituency associations.

When comparing the Conservatives' income with that of the other parties, it is clear that the patterns reported at the 2001 general election largely remained. The number and volume of all donations received by Labour (which includes trade union affiliations) was larger by some margin. For example in the final quarter of 2003, Labour received 219 declared donations totalling some $£ 4$ million - more than twice the sum received by the Conservatives. Indeed, the volume of Conservative donations after the election never once exceeded $50 \%$ of those received by Labour and on average the figure was $31 \%$. Nevertheless, by and large the Conservatives continued to receive more corporate and non-cash donations in both number and volume - the latter by some margin. In the case of individual donations however, there was a change. Whilst the Conservatives received most in number, the volume of such donations was generally of a higher value for Labour.

\section{The Large Donors}

As reported elsewhere, the new transparency engendered by the Political Parties, Elections \& Referendums Act allowed for the identification of key donors. ${ }^{2}$ In the run up to the last election, Stuart Wheeler made a donation of $£ 5$ million and made a further donation of nearly $£ 2.5$ million during the campaign. And, of course, Paul Getty gave 
some $£ 5$ million on the eve of the election. After the election, however, there were no further seven figure gifts. Indeed, until the end of 2003 at least, there were only two exceeding £250k. IIR Ltd, a ‘knowledge and skills transfer company’ made one donation of $£ 520 \mathrm{k}$ in early 2002, whilst Stuart Wheeler again contributed just over £500k in the aftermath of the fall of Iain Duncan-Smith. However, whilst there were no large individual gifts, some companies and individuals made a series of regular donations, which were smaller in size, but cumulatively large. Examples included IIR Ltd again, who made further cash donations totalling some $£ 819 \mathrm{k}$ in addition to a further $£ 92 \mathrm{k}$ of non-cash donations. Another key donor was former party treasurer, Sir Stanley Kalms. He made cash donations totalling $£ 480 \mathrm{k}$ and a further $£ 48 \mathrm{k}$ in non-cash gifts. Further key donors included Flowidea Ltd, an investment and holding company, who made a series of cash donations totalling £307k; joint founder of Hambro Magan, George Magan (who succeeded Stanley Kalms as Treasurer), who made six donations totalling £263k and Abbey Business Centres (part of the IIR Group), who made non-cash donations of £150k. In addition, as a result of the enhanced state funding engendered by both the Neill Committee and the Political Parties, Elections \& Referendums Act, the party received nearly $£ 9.8$ million in various forms of state-aid. Not all of these were new forms of money, however. Short and Cranborne money had been in existence for some while, though the amounts were enhanced post-Neill.

Despite these increases in state income, the party remained opposed to significant extensions of public provision to political parties. In its evidence to the Electoral Commission investigations into party funding, the Conservatives argued that public 
money should instead be spent on schools and hospitals, and reiterated objections made to the Neill Committee - that forcing taxpayers to fund parties that they do not support would be wrong. Instead, the party argued that the idea of tax relief for small donations should be resurrected as a means of promoting a broader funding base for the parties. This idea was included in the original Neill Committee report, but was dropped by the government, who claimed that this was state funding by stealth, since such monies would normally go to the Treasury. The Conservatives, however, argued that there was '...a clear difference between the state providing lump sum payments to a political party and the state opting not to tax money that is freely given by an individual to a party. ${ }^{3}$

\section{The Impact of IDS}

The quarterly data on donations, reported by the Electoral Commission, demonstrate some interesting patterns. First, in terms of the number of donations made overall and those broken down by companies and individuals, there had been no clear trend. However, in the last quarter of 2003, which coincided with the change of Conservative leader, donations rose both in number and in volume (see Figures 1 and 2). For example, during quarter three of 2003, a total of 73 declared cash donations were made. During quarter four of that year, there were 138. This was easily the highest number of donations in any quarter since the election, the previous high being 90 . The sharp rise was apparent in all three principal kinds of donation - individual, corporate and non-cash. Not surprisingly, the rise in the number of donations was also reflected in the volume. $£ 1.6$ million was received in cash donations in quarter four compared with $£ 689 \mathrm{k}$ in quarter three. And whilst some donations were made just prior to the fall of Iain Duncan-Smith, 
the vast majority were made after his resignation on October $29^{\text {th }} .81 \%$ of the donations in that quarter were accepted after that date, totalling $94 \%$ of the volume received. The inescapable inference to be drawn was that the change in Conservative leadership in late 2003 stimulated donations to a degree not witnessed since the 2001 general election campaign. Financially, at least, replacing Iain Duncan Smith was a successful act - at least in the short term. It should also be noted, however, that the removal of Mr DuncanSmith also coincided with a dramatic rise in the number of individual donations made to the Liberal Democrats. The party received 119 donations compared with a post election quarterly high of 55 . This generated $£ 216 \mathrm{k}$, some $£ 53 \mathrm{k}$ more in real terms than the previous quarterly post election high.

Soon after his election, new leader, Michael Howard established the Conservative Party Foundation, designed to put party finances on a sound long-term footing. The Foundation is charged with raising money for the next general election and in the longer term, building an endowment fund. To set the ball rolling, the proceeds from the sale of Conservative Central Office in Smith Square will be placed in the fund. 
Figure 1

\section{No. of Declared Conservative Donations \\ Q2 2001 - Q4 2003}

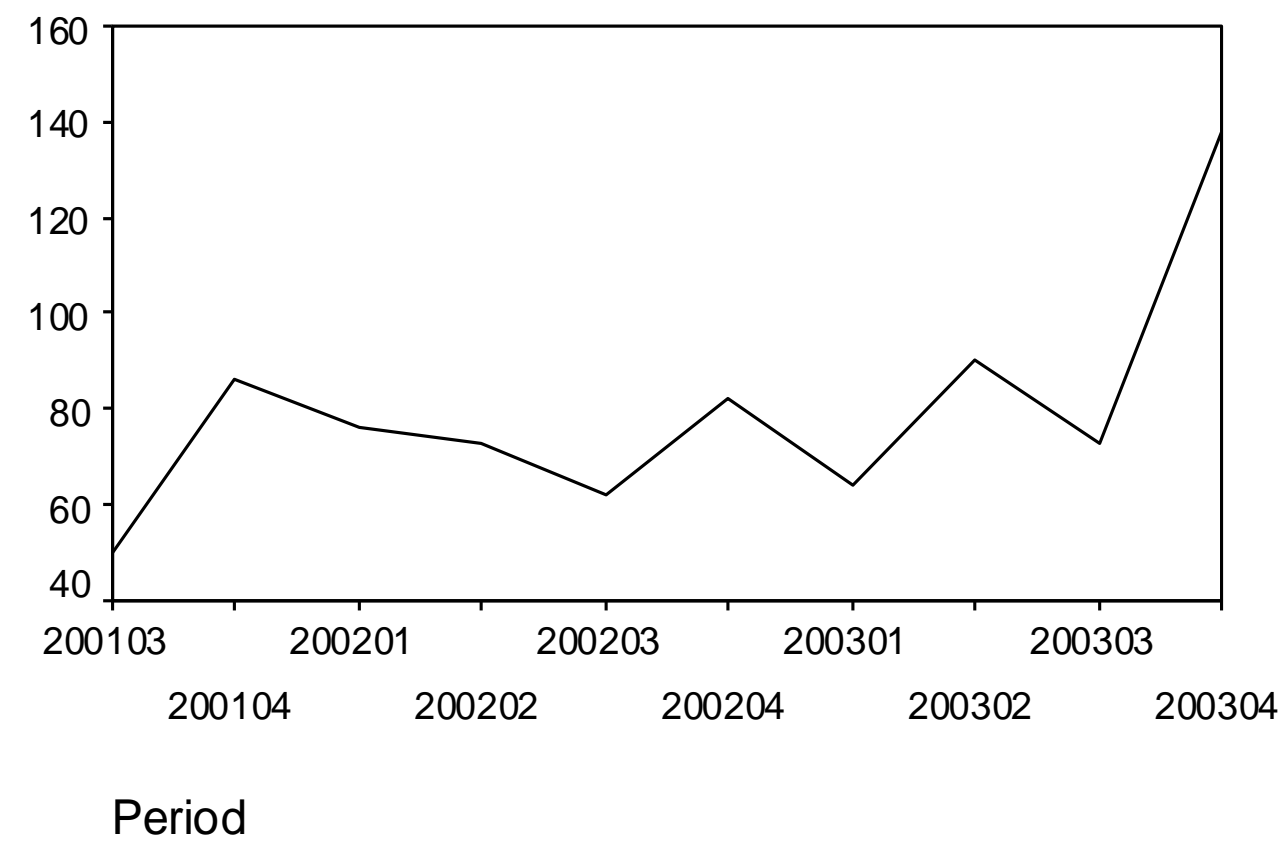

Source: Electoral Commision 


\section{Figure 2}

\section{Value of Declared Conservative}

Donations Q3 2001 - Q4 2003

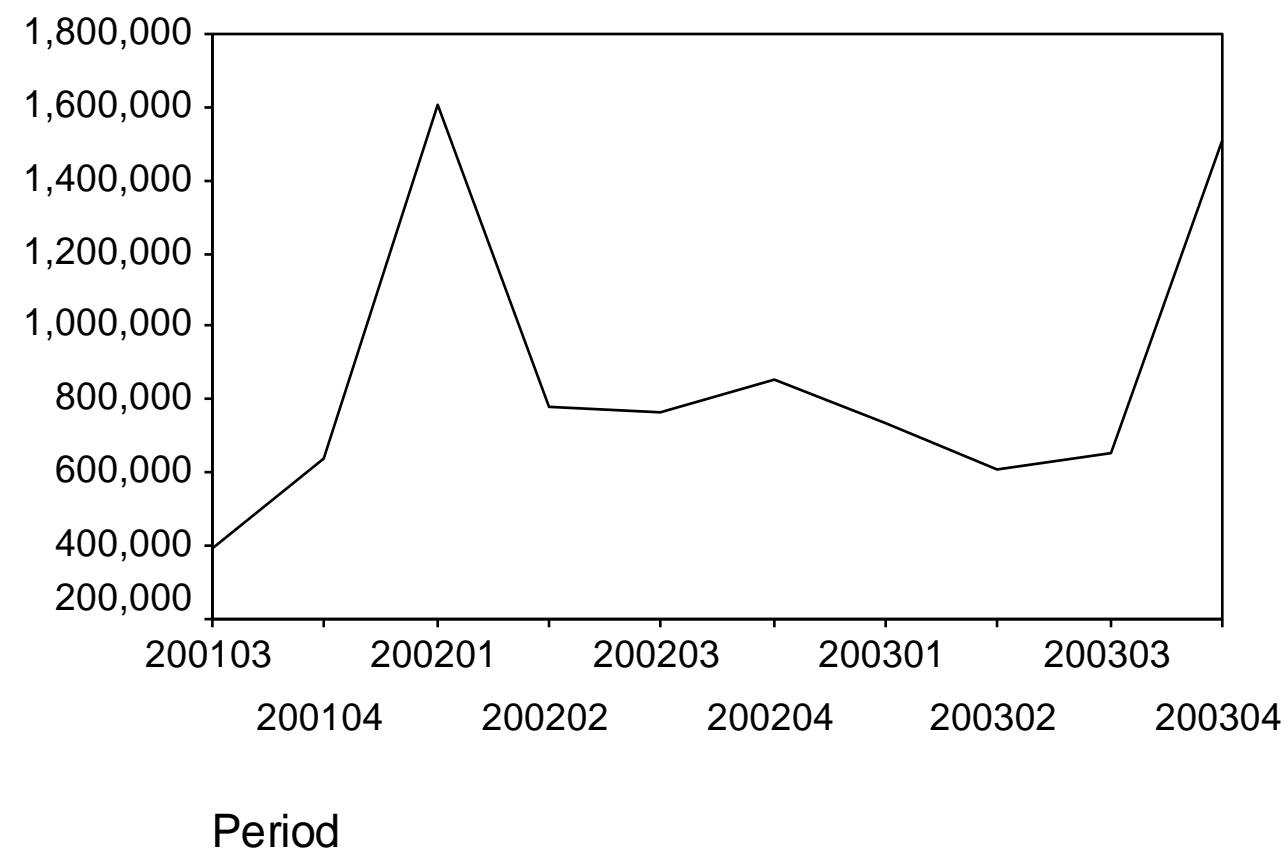

Source: Electoral Commission

\section{Money Talks?}

The study of party finance is unfortunately riddled with innuendo and half-truths, with assumptions made about the motivations of donors, which often have little basis in genuine evidence. Indeed, this problem actually increased when the new transparency regulations were first introduced. ${ }^{4}$ As in previous cases, however, there was scant evidence to support the claims that money was influencing politics. Nevertheless, two 
recent episodes in Conservative financing suggest that large donations may at least have served to highlight particular concerns.

The first episode concerned Michael Ashcroft, a former party treasurer and generous donor. In November 2003, he declared that whilst he would be contributing $£ 2$ million to enhance the party's electoral prospects, he would not be donating it to the central party. Rather, he said that constituency associations in marginal seats could apply to him for the money. His reasoning was that money needed to be targeted at marginal seats in order to reduce Labour's majority, or even defeat it at the next election. He claimed that $85 \%$ of full time agents were based safe Conservative seats and there were only 19 in marginal seats. Whilst empirical evidence suggests that his claim was something of an exaggeration, he was correct in claiming that safe Conservative seats are far more likely to employ a full time agent. Indeed, evidence shows that this has been a long-term problem for the Conservatives - their strong campaigns have often been in safe seats. And, although Fisher et al show that the central Conservative party has been more successful at channelling resources at target seats, the party is still less effective in this respect than Labour or indeed the Liberal Democrats, one likely reason being the traditionally independent stance of the constituency associations. ${ }^{5}$ The significance of Ashcroft's stance was that a large donor was able to highlight a particular problem for the party and try to alleviate it, effectively by only providing income for local parties which he considered to be worthy recipients. In electoral terms, Ashcroft's stance was entirely rational, but it raises at least some questions about the role of a donor in helping determine the party's electoral strategy. 
The second more substantive question was the role played by Stuart Wheeler in the Conservative leadership election in 2003. Mr. Wheeler had made significant donations in the run up to the 2001 election. However, in the contest to succeed the outgoing leader, William Hague, he declared that he would not back a Conservative Party led by Kenneth Clarke. In the end, despite Mr Clarke being defeated, Wheeler made only relatively small donations (totalling around £28k) whilst Mr Duncan-Smith was in charge. However, in the period just before the fall of Duncan-Smith, Wheeler publicly declared that he should be removed, calling on Conservative MPs to begin the process (which, of course, duly happened). The point here was not that Mr Wheeler expressed such a view (which as a Conservative supporter, he was perfectly at liberty to do). Rather, it was the publicity that his comments generated. In that sense, with the active compliance of BBC Radio Four (on which the declaration was made), the opinions of someone whose only political claim

to fame was that he was a significant donor, were given particular credence at a politically sensitive time. This is not in any way to cast aspersions on Mr Wheeler rather to point out that his donations had given him a platform, not provided for other Conservative supporters. And, as we have seen, soon after the fall of Duncan-Smith, Mr Wheeler's donations resumed.

\section{Electoral Commission}

In 2003, the Electoral Commission announced a review into the funding of political parties. In one sense, this might have seemed odd given that the Political Parties, Elections and Referendums Act had only been in force for a short period of time. 
However, the Act had barely been passed before questions arose as to whether the legislation had gone far enough. ${ }^{6}$ Particular attention was paid to imposing caps on donations. The Conservative response was negative. The party argued that the ability to make a donation was a mark of a free society, and that any attempt to introduce a cap was a curtailment of the rights of UK citizens. Instead, the party argued that the transparency engendered by Political Parties, Elections \& Referendums Act was sufficient for voters to decide whether donations were inappropriate. Nevertheless, whilst the party did think a cap of donations would be an infringement of rights, it did think that spending caps on parties were legitimate as a means of limiting political costs.

\section{Conclusions}

The patterns established in the run-up to the 2001 election have largely been maintained. The Conservatives are the poorer of the two main parties, but still receive more in the way at least of corporate and non-cash donations. Like the other parties, the Conservatives are under-funded, yet continue to reject the principle of significant state aid. The picture however may change. Early indications suggest that the change of leadership has stimulated donations and sustained success in mid-term elections may see that trend continue. If the party appears to be 'going places', the indications are that enhanced income will follow. Yet the party must be wary of the glare of publicity that large donations attract. The suspicion of the motives of many donors is frequently unjustified. However, the party will continue to attract unwelcome publicity (however unjustified) if donors appear to be trying to change party thinking in one way or another. 
Donation caps are one way of trying to alleviate this problem - but the Conservatives (like Labour) continue to oppose them.

Justin Fisher is Senior Lecturer in Political Science at Brunel University

1 Fisher, J. (2001) ‘Campaign Finance: Elections Under New Rules’ Parliamentary Affairs pp.689700

Fisher, J. (2002) 'Next Step: State Funding for the Parties?' Political Quarterly pp.392-9 Conservative Party (2003) 'Issues Paper: The Funding of Political Parties' Submitted to the Electoral Commission

$4 \quad$ Fisher (2002)

5 Fisher, J. Denver, D. \& Hands G. (2004) 'The Relative Electoral Impact of Central Party Coordination and Party Size at Constituency Level' Paper presented at the Political Studies Association Annual Conference

$6 \quad$ Fisher J. $(2001,2002)$ 